\title{
International synergies to address climate change: participatory community organizing in Toronto and the Baixada Fluminense, Brazil
}

\section{Introduction}

In the coming decades countries around the world will face increasingly severe challenges related to global climate change. While the details vary from country to country, the impacts will be especially grave for marginalized people, whose access to food, potable water, and safe shelter may be threatened due to fluctuations in rainfall and temperature, and to extreme weather events.

Brazil faces country-wide temperature rises, increases in vector-borne diseases, damage to fragile ecosystems (e.g., the Amazon rainforest), coral reef bleaching, changing rainfall patterns, reduced hydroelectric power supply, increased floods, and sea-level rise in highly populated coastal regions related to climate change (Pereira, 2007). In Canada, melting permafrost and Arctic ice are already dramatically restructuring northern ecosystems; changes in rainfall and storms of increasing intensity are affecting agricultural production; and urban areas face infrastructure failures due to increased rainfall.

International strategies for addressing climate change are in disarray. The complicated financial and carbon-trading mechanisms promoted by the United Nations and other global institutions are far too bureaucratic, weak, internally-inconsistent, and scattered to represent meaningful solutions to climate change. And the housing, health, and livelihoods of marginalized people worldwide are already being threatened by climate-change-related impacts. This means that the marginalized in every community, by definition, have expertise in how priorities should be set to address climate change. Their experiences, knowledge and views 
must be part of local, regional, national, and international governance - including urban planning and housing, water management, agriculture, health, and finance policies - as an essential foundation of sustainable development. This is widely recognized in the interdisciplinary theoretical literature (Perkins 2010).

As Vandana Shiva has said, " [The] best environmental education is in the minds of those that have suffered environmental destruction. It is from there that the place of learning needs to start. Here is where the knowledge lies: in the favelas, in the Amazonian villages... and with the women who work in these situations" (Shiva 2008).

A recent book on urban climate change adaptation summarizes the major challenges that low and middle-income countries face as a result of climate change:

“(M)ost of the world's urban population live in cities or smaller urban centres illequipped for adaptation - with weak and ineffective local governments and with very inadequate provision for the infrastructure and services needed to reduce climate-changerelated risks and vulnerabilities. A key part of adaptation concerns infrastructure and buildings - but much of the urban population in Africa, Asia and Latin America have no infrastructure to adapt - no all-weather roads, piped water supplies or drains - and live in poor-quality housing in floodplains or on slopes at risk of landslides. Most international agencies have long refused to support urban programmes, especially those that address these problems" (Satterthwaite et. al., 2007, p. vi). Climate change thus exacerbates already-grave sustainable development challenges.

Our concern in this paper is to examine bottom-up strategies for facing these kinds of challenges. The details of each particular community's situation-ecological, social, political— are crucial for this type of approach. How do communities organize socially and politically to 
meet biophysical and weather-related changes that affect their livelihoods? How are the needs of the most vulnerable addressed?

There is evidence that grassroots community organizing can strengthen communities' resilience to extreme weather events (Ensor and Berger, 2009). In this paper, we focus on the potential of "green community organizing" for climate change resilience and climate justice, and on how international collaboration between the global North and South can contribute to climate justice efforts.

Following an overview of the ways climate change is affecting two particular communities (one in Brazil and one in Canada), we discuss the equity and climate justice implications, and then give some examples of ways in which local community organizations are addressing these challenges through innovative programs and initiatives at the grassroots. We conclude by noting some similarities in these stories from the Global North and South, and some ways in which communication and mutual reinforcement can strengthen and inspire global climate justice work.

\section{Climate change and marginalized people in Rio de Janeiro and Toronto}

In a warming world heavier and more frequent precipitation is likely. This section endeavours to explain the impact of recent extreme weather events on marginalized populations in the areas around Rio de Janeiro and Toronto - places where we have conducted research on this issue. We use these two areas as examples to show the kinds of local impacts and community-based responses to climate change which we believe are being repeated, of course with locally-specific variations, all over the world. 
After São Paulo, Rio de Janeiro is the second largest city in Brazil with over six million inhabitants. Located on Guanabara Bay on the southeastern coast of Brazil, Rio, like so many other coastal cities, will be challenged by climate change. Issues that may exacerbate Rio's environmental problems are social and waste-related ones, such as illegal settlements, flow of sewage from slums into rivers, and industrial byproducts (De Sherbinin, Schiller and Pulsipher, 2007, p.50-53). The shoreline has changed drastically since the colonial era. Once outlined by wetlands, lagoons and inlets, these shoreline areas have been filled in, exacerbating summer flooding between January and March. These wetlands and the mangroves around Guanabara Bay, most of which were removed to make shipping lanes, used to contribute significant absorptive capacity. The coastal mountains that form the landscape of the city were once covered by Atlantic rainforest. Over time, housing and favelas (precarious hillside slums) have replaced much of the forest cover, and the mountains are now disposed to landslides and erosion (p.51). Favelas, where approximately 1.1 million people live, represent almost twenty percent of the municipality's inhabitants. These communities are always hard-hit by storms (pp.53-54).

The potential impacts of both temperature and precipitation extremes for the city of Rio de Janeiro are many. Climate projections show that Rio will experience a 1.5 degree Celsius increase in temperature by 2050 across all seasons. With warmer temperatures, drought can be expected in winter, spring and summer. This will likely create water scarcity, as well as electricity deficits from shortfalls in hydroelectric production. Increases in ocean surface temperatures, however, could increase the chances of periodic and extreme storms and flooding. With climate change, extremes in precipitation are projected to increase in intensity (De Sherbinin et al., p.56).

In April of 2010 heavy rains partially destroyed several downtown favelas in Rio de 
Janeiro and Niteroi (across Guanabara Bay), leaving thousands homeless and forced to relocate with their families and remaining belongings (O Globo, 2010). Also severely hit by heavy rainfall in January 2011 was the Região Serrana, a mountainous region in the state of Rio de Janeiro to the north and northeast of Guanabara Bay. Housing infrastructure and social inequities compounded the effects of natural disasters on the marginalized in the Região Serrana; in the town of Nova Friburgo, where several hundred people died due to the recent floods, sixty percent of the population lived in illegal dwellings (Magalhães, 2011).

In Toronto, the effects of climate change are being noted particularly through high amounts of summer rainfall and sudden storms with intense winds and heavy rain, which seem to be becoming more frequent (Todd, 2011). Higher amounts of rainfall stress the aging urban water/sewer infrastructure, resulting in overflows of untreated sewage from the combined storm and sanitary sewers in the older parts of downtown Toronto during heavy storms, degrading water quality in local streams and Lake Ontario (Binstock, 2011). At times, local lakefront beaches are posted as unswimmable due to water pollution for several days following heavy rains. The City of Toronto is undertaking several large infrastructure repairs and has built storage basins to retain sewer overflows until they can be treated, at a projected total cost of $\$ 1.047$ billion over 25 years (City of Toronto, 2011a). The City has also launched basement flooding studies and programs to help homeowners disconnect their basement drains leading to the municipal sewer system, in order to prevent backups into basements during rainstorms. The increasing numbers of extremely hot days in the summer have led the City to develop a "cooling centres" program where those without air conditioning can come to public libraries, community centres and other communal spaces which offer extended hours on very hot days.

From an equity perspective, both the weather extremes and the resulting policies have 
disproportionate negative effects on low-income Toronto residents, since they are more likely than higher-income people to occupy basement apartments and to be renters, not house-owners (who can, in contrast, benefit from government infrastructure subsidies). Lower-income people are also more likely to depend on public transit (which is often disrupted during storms) and on public beaches and parks for recreation; they are less likely to have air conditioning in their homes; and they are more likely to have health conditions which are severely exacerbated by heat, such as diabetes, high blood pressure, and heart conditions. These equity implications have been noted in some reports, but have yet to be quantified or estimated in official publications or policy frameworks.

One particular low-income neighbourhood in Toronto has borne the brunt of several recent extreme weather events. It is the Jane-Finch neighbourhood, located in northwest Toronto near York University. Due to dense urban growth and university development, the area has become increasingly built-up over the past decade, which has increased the surface runoff into Black Creek, a tributary of the Humber River that empties into Lake Ontario. During an intense storm in August 2005, more than $150 \mathrm{~mm}$ of rain fell in the area, and normally-placid Black Creek became a rushing torrent which washed out its culvert under Finch Avenue, a local arterial roadway, leaving a 50-meter-wide gaping hole. Construction of a new bridge for Finch Avenue took six months and cost more than $\$ 3$ million. During this time, public buses and commuter traffic had to be rerouted through the York University campus, causing delays and problems for the university and local residents alike. This was a graphic example of how extreme weather events - which are increasing in frequency due to climate change - in conjunction with aging infrastructure and urban sprawl (including campus development), and increasing rapid rainfall runoff can have costly and traumatic effects on everyone in the watershed. 
All over the world, climate-change-related extreme weather events affect marginalized people first and hardest. The Toronto and Rio de Janeiro examples cited serve to indicate some of the ways that these impacts make themselves felt.

\section{Green community organizing in Rio de Janeiro and Toronto}

While environmental problems have been a source of concern in both areas for years, climate change is raising these issues on local agendas. In this section, we summarize how organized community groups in each city are addressing long-standing priorities of job creation, economic opportunities, and need for recreational space while also beginning to respond to the local effects of climate change.

\section{Água Doce: water and livelihoods in the Baixada}

At the western edge of Guanabara Bay, in an economically-depressed area of the Baixada Fluminense around the Surui River, the community development organization Água Doce (Sweet Water) has been building social resilience, fostering local cultural pride, and creating green jobs. Started by Vladimir Boff and Maria Regina Maroun in 2001, with seed funding from several Italian labour union and church organizations, Água Doce's initiatives include community centres and kindergartens; biodigesters and a biomass recycling centre; agricultural support offices and fruit processing centres to process locally-grown fruits and create jobs for women; handicrafts training and support for women and girls; public health projects; and a public library/literacy centre (Centro Clima, 2005, pp.57-64).

The Água Doce organization, reinforcing Agenda 21 principles, aims to (re)introduce a 
more sustainable way of life to the people of the Baixada Fluminense through a range of social and economic community development initiatives.

People at Água Doce and the communities of the Baixada Fluminense are particularly concerned about the imminent effects of climate change in the region, mostly due to their precarious geographical location. Increased rainfall from the mountains and rising sea levels from the Bay make the area particularly vulnerable to floods and mudslides. Health risks from water-borne illnesses are increasing. Fishing and crabbing are progressively endangered.

The people of Água Doce believe in nurturing social capital in order to strengthen communities in the region. The organization offers literacy and environmental education workshops and supports schools and children's programmes, as well as creating economic opportunities for women.

Água Doce promotes social transformation and building the capability of local citizens to participate in decision-making processes, especially concerning water, resource management, and local governance.

The organization has mobilized funds from a range of religious, private sector, international development assistance, and other donor organizations for its projects. Their work demonstrates the inter-linkages among literacy, economic, and social supports including job creation and community-building, and the potential of marginalized community members to become involved in collective decision-making. The organization's attention to ecological sustainability, social sustainability, and governance provides a wealth of ideas for ways of integrating community members' environmental priorities with other pressing needs in the community, and advancing on many fronts at once through community development. 


\section{The GreenXChange Project: environmental development and jobs in Jane-Finch}

Since 2009, the Jane-Finch community in northwest Toronto has built a vibrant and growing initiative to create jobs while greening the local community. The project began with concerns of residents in local public housing buildings about waste management and energy conservation; about having no control over heating; about not having a place to recycle or compost; and about not being able to see any benefit to switching to more expensive compact fluorescent light bulbs. Residents were concerned about the costs that new "smart meters" would add to their monthly electricity bills. They were concerned about meagre waste management services available to them in their buildings. In the larger community, residents were concerned about storm water management and flooding in the area, especially following the 2005 Finch Avenue washout.

The Jane-Finch Community and Family Centre (JFCFC), a community-based social services organization, decided to build on the desire of community residents to be more ecofriendly and seek ways to expand community greening efforts beyond their own offices in one Toronto Community Housing building. The JFCFC applied for funding and created partnerships with the Toronto Community Housing Corporation, the Toronto and Region Conservation Authority, and the NGO Zerofootprint to make Green Change happen in the community. Together they developed a 45-hour training program for Green Change Agents and put out a call for community volunteers to participate in the training. The training program introduced residents to five key areas: energy conservation, waste management and recycling, green active living, social justice, and the green economy. Many residents signed up and participated in different aspects of the training and 60 residents completed the entire program - earning the right to call themselves Green Change Agents. 
After finishing their training, the Green Change Agents shared their knowledge with the community by using an online calculator tool developed by Zerofootprint (www.zerofootprint.net) to document the carbon footprint of more than 900 households in the Jane-Finch area. Agents were paid for each household assessment they conducted. The Zerofootprint calculator measured and analyzed the carbon footprints of individuals and households in the Jane-Finch community and also provided tips for Green Change Agents to use to help community members save energy, save money, and be able to reduce their carbon footprints. In 2010, Green Change Agents assisted residents in reducing their carbon footprint by 2000 tonnes.

Many green changes have been made in the community, including the planting of a community garden, an eco-friendly Earth Hour event at a local school, tree planting for Earth Day 2010, and a celebration of Earth Day 2011 in a space that was secured as a Centre for Green Change. At the Centre for Green Change, a community training facility modelling green building techniques, local residents and youth concerned about the protection of the environment can become engaged in the process of green change and mobilize others, while they increase their own knowledge and skills, initiating individual and collective actions toward building a healthy, safe, prosperous, and environmentally friendly neighbourhood. The vision for the Centre includes a Pathways to Green Jobs Program, which will educate and promote environmental stewardship, green jobs, and eco entrepreneurship. It will build on the successful work of the Carpenters Union's CHOICE Apprentice Program and will incorporate an environmental training component. The Centre for Green Change works with residents to create and to innovate and to use their hands and creative minds while protecting the community's natural resources. The Centre will mobilize local resources to achieve this vision and explicitly 
work to expand the number of long-term, high-quality green jobs for local residents, especially for youth.

The Green Change Project held successful gala fundraising balls in 2010 and 2011, as part of its celebration of "Twelve Days for Green Change," with the support of a number of community partner organizations including labour unions, health centres, local politicians, property owners and landlords, charitable organizations, and cultural/media groups. In 2011, it has changed its name to the "GreenXChange Project" to acknowledge these partnerships and the many exchange opportunities generated by its green community development work. The project continues to win awards and accolades, including the 2010 Toronto Green Award in the Community category and the 2011 Urban Leader Award for Imagination.

Reasons for the project's success include its focus on connecting with the community directly and its emphasis on local skills and needs. The project aims to identify the skills and knowledge already present within community members and to empower them to use these assets for green change. The level of skills and knowledge in the Jane-Finch community is significant. Many neighbourhood residents are recent immigrants to Canada, and many of them come highly trained and skilled from their home countries, but are unable to break the barrier of employment in Canada. The Green Change project recognizes the skills and abilities of these individuals and aims, through Green Change Agent training, to create jobs. These individuals benefit from being able to financially support their families and also to contribute to the development of their community.

Participants in the Green Change Agent training find themselves being treated with respect in the community for the knowledge and skills they can offer for change. The title Green Change Agent has allowed the individuals to gain respect on a par with environmental specialists 
in the area.

\section{Common themes in green community organizing}

A number of commonalities are evident in the local stories outlined above. Marginalized people everywhere are eager for employment opportunities, and public space for recreation and community-building is almost always in short supply in marginalized neighbourhoods. Local governments can play an important role in helping communities meet their needs, especially if people are mobilized and organized politically at the grassroots - which can be effectively catalyzed by NGOs. Infrastructure funding and climate change adaptation funding may be available when local requirements are framed in appropriate ways. New, creative techniques for green community organizing are developing rapidly, aided by global networking advances and the hard work of many local and international activists. In combination, all of these trends are helping to strengthen resilience in many communities, allowing them to mobilize socially to meet new ecological and weather-related challenges.

In this section, we discuss a number of international commonalities and themes related to green community organizing in the face of climate change.

\section{Green job creation}

In marginalized communities people are nearly always interested in increasing their employment opportunities. High levels of unemployment — that is, community members who are eager for training and work opportunities — represent a significant resource for poor communities, since environmental restoration and low-fossil-fuel production require large 
amounts of people-power. Examples of the kinds of green job creation which are needed in poor

—and also well-off—communities include wetlands reconstruction; rebuilding and strengthening water/sewer and other infrastructure; rehabilitation of polluted areas, brownfields, and transportation corridors; construction and maintenance of rooftop, roadside, and other community gardens; processing of locally-grown food; and development of new recreation options on land which is not appropriate for housing or industry. Funding which is available for infrastructure renewal and climate change adaptation can be used to support and catalyze these kinds of green jobs, producing powerful local economic benefits.

\section{Community-building to develop social resilience and political intervention potential}

NGOs with local roots and long-standing community centres and social services organizations have important roles to play in marginalized communities' response to climate change. Their contributions can include bringing people together to prepare for extreme weather events; collecting knowledge on the local weather, water, and environment and bringing it to the attention of governments; developing social networks for community resilience; and organizing community members politically to express their views and advance their priorities.

\section{Recreation spaces as flood buffers}

Low-income communities with many unemployed people, especially youth, need recreation spaces, and these are usually in short supply. Increased weather variability and rainfall are expanding the subject to flooding and thus not appropriate for housing. A good alternative use for these areas is as public spaces, swimming / picnicking areas, and sports fields. If governments can equitably assist people to relocate from floodplains to higher areas nearby, 
simultaneously creating jobs and community-controlled spaces in these areas, then climate change adaptation can accomplish several goals at once.

\section{Mobilizing finance for infrastructure renovation}

NGOs and government bodies may be able to use international connections and climate change funding mechanisms, both formal and informal, to carry out projects such as water/sewer infrastructure renewal and development, renewable energy plants, housing reconstruction, and public space provision. The "guilt factor" motivating progressive Northern groups who recognize the responsibility of the wealthy for climate change, and who take action to fund remediation projects in the global South, lies behind some of these new global redistribution initiatives.

\section{Creative organizing/workshop techniques/strategies and international sharing of ideas}

Ideas, designs, and financing proposals can be shared internationally through green/climate change channels. For example, the United Nations Framework Convention on Climate Change annual COP meetings have facilitated networking by a wide range of community-based environmental NGOs which have participated in the civil society forums accompanying the governmental negotiations. Likewise, Majora Carter's advocacy work highlights the common strategies marginalized areas can use in sparking green community development throughout the global North and South.

\section{Role of municipal government and public education}

Cities worldwide have begun to develop climate change adaptation plans and to take 
stock of their new needs_-physical, social, economic (Lucon and Goldemberg, 2010). If community groups organize to share their expertise and knowledge of the challenges, as well as ideas on how to meet the challenges, they may be able to build beneficial partnerships with local governments. Public officials everywhere need training in all aspects of climate change preparedness, and environmental education for the general public is also crucial in a warming world. Here, too, networking and global communication help groups to learn from "best practices" and creative ideas in use elsewhere.

\section{Conclusion}

Climate justice - expressly addressing the impacts of climate change on the poorest first -is a powerful imperative at every level, from the local to the global. Civil society groups worldwide are using online and in-person networking tools to share ideas on how to promote climate justice, to obtain funding, and to press politically for policies addressing the needs of marginalized people. This bottom-up movement builds resilience in the face of the social and political repercussions of extreme weather events - a global priority, since we are all in this warming world together. 


\section{References}

Bielski, Z. (2008, July 12). Intense storm leaves beaches flooded, homes flooded. Retrieved May 8, 2011, from National Post: http://www.nationalpost.com

Binstock, Matt. (2011). Greening Stormwater Management in Ontario. Retrieved June 23, 2011. Toronto: Canadian Institute for Environmental Law and Policy (CIELAP). Available online at http://cielap.org/pub/pub_greeningstormwaterman.php

Centro Clima. (2005). The South-South-North-SSN Project. Potential Adaptation Projects Report: Brazil. Accessed July 14, 2011. Available

at: http://www.southsouthnorth.org/download.asp?name=SSN2_Report_Adaptation\%20Context $\% 20$ final4.pdf\&size $=4814863 \&$ file $=$ documents/SSN2_Report_Adaptation $\% 20$ Context_ $\% 20$ final4.pdf

City of Toronto. (2005, September 30). City approves basement flooding subsidy for homeowners. Retrieved May 8, 2011, from http://wx.toronto.ca/inter/it/newsrel.nsf/0/3f3a65ce7d283fdd8525708c006aa028?OpenDocument

City of Toronto. (2011a). WWFMP - Going for the flow. Retrieved May 8, 2011, from http://www.toronto.ca/water/protecting_quality/wwfmmp/about.htm

City of Toronto. (2011b). Coatsworth Cut sewer upgrades construction. Retrieved May 8, 2011, from http://www.toronto.ca/involved/projects/coatsworthcut/index.htm

City of Toronto. (2011c). Projects. Retrieved May 8, 2011, from http://www.toronto.ca/involved/projects.htm

City of Toronto. (2011d). Black Creek Boulevard. Retrieved May 8, 2011, from http://www.toronto.ca/involved/projects/black_creek_blvd/

City of Toronto. (2011e). Hogg's Hollow - Road reconstruction. Retrieved May 14, 2011, from http:/www.toronto.ca/involved/projects/hoggshollow/index.htm\#a4

Climate Consortium for Research Action Integration (CC-RAI). 2011. Where does the water go?: Evapotranspiration in Toronto. Retrieved May 12, 2011, from http://www.climateconsortium.ca/2011/01/24/where-does-the-water-go-evapotranspiration-intoronto/

de Oliveira, J. A. (2009). The Implementation of Climate Change Related Policies at the Subnational Level: An Analysis of Three Countries. Habitat International, 33, 253-259.

de Sherbinin, A., Pulsipher, A., \& Schiller, A. (2007). The Vulnerability of Global Cities to Climate Hazards. Environment \& Urbanization, 19 (7).

Ensor, Jonathan and Rachel Berger. (2009). Understanding climate change adaptation: lessons from community-based approaches. Bourton on Dunsmore, UK: Practical Action Publishing.

Figureido, Patricia and P.E. Perkins. (2011). Gender justice and climate justice: Community-based strategies to increase women's political agency in watershed management in times of climate change. Paper presented at the Ninth International Conference of the International Development Ethics Association (IDEA), Bryn Mawr College, Pennsylvania, June 9-11, 2011.

GreenXChange Project. (2011). Accessed June 23, 2011. http://www.greenxchange.ca/general/green-change-project-notes

IPCC - Intergovernmental Panel on Climate Change. (2007). Climate Change 2007: ThePhysical Science Basis. Contribution of Working Group 1 to the Fourth Assessment Report of the Intergovernmental Panel on Climate Change [S. Solomon, D. Qin, M. Manning, Z. Chen, M. 
Marquis, K.B. Averyt, M. Tignor, \& H.L. Miller (Eds.). Cambridge, UK and New York: Cambridge University Press.

Jane-Finch Community and Family Centre. (2011). Accessed June 23, 2011. http://www.janefinchcentre.org/

Lucon, O., and Goldemberg, J. (2010). São Paulo -- The "Other" Brazil: Different Pathways on Climate Change for State and Federal Governments. The Journal of Environment and Development , 19 (3), 335-357.

Magalhães, L. E. (2011, January 22). Friburgo tem 60\% dos imóveis ilegais; um deles, vizinho a encosta que deslizou, tem 10 andares. Retrieved January 22, 2011, from O Globo: http://oglobo.globo.com/rio/mat/2011/01/21/friburgo-tem-60-dos imoveis-ilegais-um-delesvizinho-encosta-que-deslizou-tem-10-andares-923586240.asp

O Globo. (2010, April 11). Cabral anuncia R\$ 1 bilhão em habitação para desabrigados pelas chuva. Retrieved February 15, 2011, from O Globo:

http://oglobo.globo.com/rio/mat/2010/04/11/cabral-anuncia-1-bilhao-emhabitacao- paradesabrigados-pelas-chuvas-916315287.asp

O’Neil, L. (2010, June 27). Union subway station, DVP, major downtown roads closed due to flooding. Retrieved May 8, 2011, from Toronto Star: http://www.thestar.com

Perkins, Patricia E. (2010). "Public participation in watershed management: international practices for inclusiveness." Physics and Chemistry of the Earth. http://dx.doi.org/10.1016/j.pce.2010.02.004

Pereira, E. L. (February 2007). Brazil \& Climate Change: a Country Profile. Retrieved January 2011, from SciDev.Net: http://www.scidev.net/en/policybriefs/brazil-climate-change-acountry-profile.html

Portal do Governo do Estado de São Paulo. (2010, June 24). Governo regulamenta lei de mudanças climáticas. Retrieved March 26, 2011, from Governo do Estado de São Paulo: http://www.saopaulo.sp.gov.br/spnoticias/lenoticia.php?id=210829

Powell, Rosemarie, E. Lorimer and E. Perkins. (2011). The GreenXChange Project: environmental development and jobs in Jane-Finch. Unpublished paper, York University and Jane-Finch Community and Family Centre, Toronto.

Riversides. (2009). The Toronto rain storm 2005. Retrieved May 5, 2011: http://www.riversides.org/rainguide/riversides_hgr.php?cat=1\&page=78\&subpage $=82$

Sandink, D. (2007). Diary of urban flooding. Retrieved May 5, 2011, from Canadian Underwriter: http://www.canadianunderwriter.ca/issues/story.aspx?aid=1000217381

Satterthwaite, David, S. Huq, H. Reid, M. Pelling and P. Romero Lankao. (2007). Adapting to climate change in urban areas: The possibilities and constraints in low- and middleincome nations. (Accessed July 14, 2011). International Institute for Environment and Development, Human Settlements Discussion Paper Series, Climate Change and Cities - 1. Available online at: http://www.iied.org/HS/topics/accc.html and www.iied.org/pubs/display.php?o=10549IIED.

Shiva, Vandana (2008). Quoted in the film, "Somos todos aprendizes: Tratado de Educacão Ambiental," Brazilian Ministry of Environment, Ministry of Education, Ecoar Institute for Sustainability, et.al.

Sustainable Neighbourhood Retrofit Action Plan (SNAP). (2011). Black Creek SNAP. In SNAP Neighbourhoods. Retrieved May 7, 2011, from http://www.sustainableneighbourhoods.ca/neighbour/black-creek.dot

Todd, Alexander. (2011). Climate change and water governance in the Greater Toronto 
Area. Unpublished paper, York University, Toronto. 